\title{
Eco-Physiological Study of Marshy and Sandy Habitats of Kachchh
}

\author{
Suhas J. Vyas ${ }^{1}$, Dipika Kara ${ }^{2}$ and Savan Tank ${ }^{3}$ \\ ${ }^{1 *}$ Department of Life Sciences, Bhakta Kavi Narsinh Mehta University, Junagadh, India \\ ${ }^{2}$ Department of Earth and Environmental Science, KSKV Kachchh University, Bhuj, India \\ ${ }^{2}$ Department of Earth and Environmental Science, KSKV Kachchh University, Bhuj, India \\ *Corresponding Author: vsuhas.13@gmail.com Contact +91-9925016914
}

Available online at: www.isroset.org

Received: 02/Nov/2017, Revised: 15/Nov/2017, Accepted: 12/Dec/2017, Published: 31/Dec/2017

\begin{abstract}
The Kachchh coast is an ecologically sensitive zone as it supports vast areas of Mangroves, Corals, mudflats and the various components of the ecology are interlinked into a fragile ecosystem. The mangroves help the ecosystem by contributing to the oxygen Budget and in Soil Conservation. Mangroves and Corals are the nursing grounds for a variety economically important fishes, exotic coral fishes and innumerable flora and fauna. Conservation plan for patchy corals of the Gulf of Kachchh is reported. Present a detailed discussion on mangroves of the Gulf, marine floral and faunal wealth and the environmental problems like exploitation of mangrove vegetation, salt pans etc. Case studies on feasibility and conceptual plan for oceanarium, dolphinarium, marine land complex are discussed for conservation of marine life. Study aspect on the restoration of mangrove forest in detail. Ecology and biodiversity of Indian mangroves have been reviewed. Coastal and marine environment of Gulf of Kachchh has been chosen for development of model coastal management plans. Proposed establishment of refineries along the southern shore of the Gulf of Kachchh and eventual increase in the movement of crude oil and petroleum products high lights the urgent need of an adequately evolved environment management plan to minimum adverse impacts on the rich and diverse bio-productive regime of the Gulf. The various physico-chemical parameters were analyzed and study of marshy and sandy habitat in Kachchh region Texture found Sand $>$ Silt $>$ Clay in all samples. parameter of soil like pH 7.5, Sodium $190 \mathrm{mg} / \mathrm{l}$, Calcium $0.23375 \mathrm{mg} / \mathrm{l}$, Magnesium $0.40075 \mathrm{mg} / \mathrm{l}$. Total Hardness 0.635mg/l, Chloride $3.552 \mathrm{mg} / \mathrm{l}$, Potassium $106 \mathrm{mg} / \mathrm{l}$.
\end{abstract}

Keywords - Chemical parameter, coastal zone, ecologically sensitive zone, marshy area, physical parameter

\section{INTRODUCTION}

Physicochemical properties of the soil of the coastal plains adjacent to the Sea of Japan and the Sea of Okhotsk are described. Data are compared with data on similar soils in other parts of the world. a number of groups of soils of the coastal plains are distinguished.

As this study partly deals with 3 mangrove species occurring in the Gulf and marshy areas, a passing reference should be made on this group of plants. It is widely accepted that mangrove ecosystems are diverse communities growing in the inter-tidal zones of tropical to sub-tropical coastal rivers, estuaries and bays [52]. Moreover, they act as a barrier against cyclones, protect coastal erosion and provide good nursery ground for a number of commercially important aquatic organisms. The study was carried out as part of a programme, which aimed to conserve Kavvayi wetland because of its unique ecological and environmental characteristics [50].
Floristic composition as is a good floristic marker, because any kind of changing floristic compositions in different endogenous milieu show the existence of different ecological factors; thereby leading to inter-and intra-specific diversity. This has been established in various studies [44, 45]. However, there are few studies on using and emphasizing phyto-sociological parameters to elaborate diversity of coastal flora.

Gujarat coast is characterized by typical salt marshes spread in about $796-\mathrm{km}$, sand-dunes in approximately $440-\mathrm{km}$ and rocky shores in 319-km [38, 39].

Aquatic ecosystems are the most productive ecosystems and provide a resource of food and raw materials with a very high economical value to the national and regional economy. [29, 54] These fragile ecosystems include different biotopes like; sand-dune, marshes, lakes and rivers. Much work has been carried out on the floristic, phyto-sociology and pollution aspects of these ecosystems in different regions of the India and world notable among these being $[1,2,18,30,32]$. 
Processes of climatic change and habitation loss which alongside are an important example where synergistic effects may occur. Yet most studies reporting effects of climate change [33] or habitat loss and fragmentation on biodiversity [7] have examined each in isolation. The soil plays an important role in the productivity of crops as well as the improvement in environment [55].

A sensitive and useful evaluate of biodiversity loss needs to be based on changes in population abundance across a large range of species and must consider the entire landscape. At a global scale, habitat loss, including reductions in both quality and quantity of suitable environment, is the main factor responsible for declines in species abundance [15]. Other important cause, such as excessive harvest pressure or the effect of pollutants, can also be articulated on the basis of area affected and intensity of impact.

\section{RELATED WORK}

The study of Sea grass communities are the critical part of the marine ecosystem because they function as primary producers with high rate of production [10] and serve as shelter and swim-in-restaurants for a variety of marine animals [17] Marine botanists have rigorously worked out eco-physiology of sea grasses, which abundantly grow in tropical and temperate seawaters [13] described the distribution of seagrasses along the Indian coast, whereas [42] studied ecophysiology of Ruppiaro stelata growing on Saurashtra coast in Gujarat.

Accounts of salt marsh ecology with particular emphasis on vegetation and topography appear [3, 4, 9, 24, 39, 49] while other aspects are included.

It may be mentioned here that the IUCN in its regional marine program for 15 countries in Asia (2002) further stressed the need to save from harm coastal and marine diversity covering a varied range of ecosystems, such as coastal lagoons, mangroves, coral reefs, marshlands and deep sea trenches.

Base data of mangrove diversity in the Sunder bans (India) have been collected [30] whereas massive investigations on coastal flora occurring on 5700-km-long Indian coast have been cited by Banerjee [2]. However, these studies, though many in numbers, include only details of either occurrence or distribution of halophytes in different parts of the country. The Significant contribution on eco-physiology, phytosociology and biodiversity of halophytes has been carried out at Physiology laboratory of Life Science Department since 27 years $[19,34,46,48,50]$ Nevertheless, much remains to be done on diversity of coastal flora occurring on Indian coast.

In a broader sense, coastal systems include rocky and sandy shores, beaches, estuaries, deltas, backwaters, lagoons etc. [6] and are usually covered with dry coastal beach vegetation, beach forest of sandy or rocky habitat types, wet coastal mangroves, salt marshes, seaweeds, sea-grasses, coral reefs and associated sub-tidal benthos [11]

Kirtikar and Basu, studies on mangrove and identified to tolerate extreme and any environmental condition. [20]

Halophyte is a plant who grows in saline area and also affected by salinity in root area. Mangrove and halophytic plants have been used in folklore medicine for the treatment of human diseases for centuries.

Distribution of various plant species in coastal environment depends upon their capacity of enduring salt tolerance and the latter characteristic is often manifested by the mineral composition of vegetative organs. Khot[19] reported 2.94 to 12.3 meq. $\mathrm{g}^{-1} \mathrm{Na}^{+}$and 2.6 to $11.6 \mathrm{meq} \cdot \mathrm{g}^{-1} \mathrm{Cl}^{-}$and Shukla [46] found 3.64 to 5.86 meq.g ${ }^{-1} \mathrm{Na}^{+}$; and 4.55 to 6.97 meq.g ${ }^{-} 1 . \mathrm{Cl}^{-}$ in different succulent halophytes Most of salt tolerant grasses are usually salt excretes and therefore, accumulate less a mounts of $\mathrm{Na}^{+}$and $\mathrm{Cl}^{-}$. For example, Joshi [16] reported 0.15 to 0.78 meq. $\mathrm{g}^{-1} \mathrm{Na}^{+}$and 0.15 to 0.53 meq. ${ }^{-1} \mathrm{Cl}^{-}$in vegetative organs is salt tolerant grass Heleochloa setulosa collected from Ghogha area, Gujarat. Misra [28] observed that accumulation of $\mathrm{Na}^{+}$varied from 0.32 to $0.66 \mathrm{meq} . \mathrm{g}^{-1}$ and that of $\mathrm{Cl}^{-}$from 0.37 to 0.77 meq.g ${ }^{-1}$ in Sporobolusm adraspatanus. Recently, Vyas and Pawar [34, 50] recorded 1.02 to 1.37 meq.g ${ }^{-1} \mathrm{Na}^{+}$and 1.53 to 1.59 meq.g ${ }^{-1} \mathrm{Cl}^{-}$in Sporobolus coromandellianus and Aeluropus lagopoides growing in Bhal' and lower part of Gujarat region.

\section{METHODOLOGY}

Description of the study area

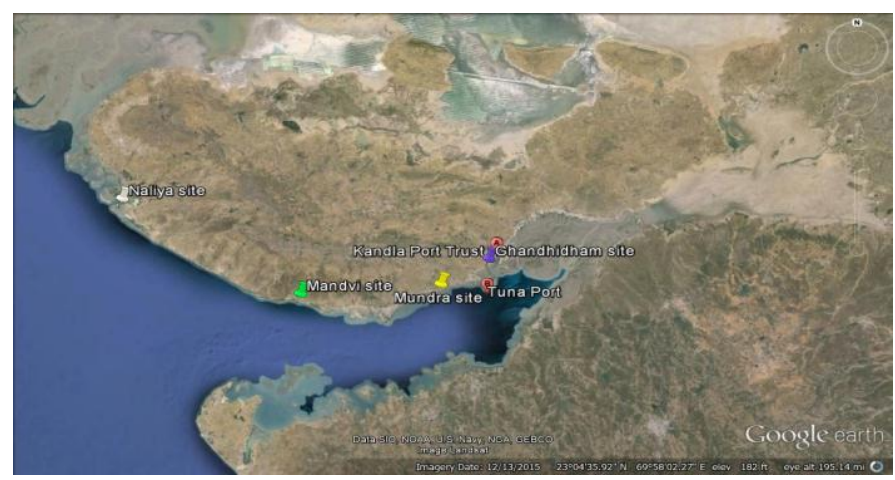

Fig. I

Jakhau: It is situated Latitude $23 \cdot 13$ '48.59' $\mathrm{N}$ \& Longitude $68 \cdot 36$ '56.54' $\mathrm{E}$. The area is famous and one of the oldest ports on Kachchh coast. Creeks of Jakhau are also well known for very productive salt pans, dense patches of natural mangroves and also identified as one of the important sites for mangrove plantation by various agencies. A part from port 
and salt pan activities, the area is known for seasonal fishing activity, especially for prawns.

Bhadreshwar: It is situated at Latitude 22.58 ' $30.25 \mathrm{~N}$ \& Longitude $69 \cdot 54^{\prime} 20.98^{\prime}$ ' $\mathrm{E}$. It is about $27 \mathrm{~km}$ from Taluka headquarter Mundra and barely a kilometer away from seashore. The Bhadreshwar has been included in special economic zone of Mundra.

Mandvi: one an important port city of the region and dates back to $16^{\text {th }}$ Century AD. It is situated Latitude $22 \cdot 49$ '24.15''N \& Longitude 69.20'26.64'' E. The city had more than four hundred year old ship building industry that still manufactures small ships. In 18th century, the Mandvi merchants collectively owned a fleet of 400 vessels trading with East Africa, Malabar Coast and the Persian Gulf.

Gandhidham (Tuna): It is situated Latitude $22 \cdot 58^{\prime} 30.25^{\prime}$ ' $\mathrm{N} \&$ Longitude $70 \cdot 05^{\prime} 54.50$ ' $E$.Tuna port was developing during mid'eighteenth century by Roa.

Collection of soil sample

Sample of soil were collected around $5 \mathrm{~kg}$ of $10 \mathrm{~cm}$ deep depth. Samples were collect from the Mandvi, Mundra (Bhadreswar), Abdasa (Jakhau), and Gandhidham (Tuna) area. Soil samples were collected in ziplocked polythene bags.

\section{RESULTS}

The highest percentage of silt content recorded $32.44 \%$ in jakhau and low percentage of soil silt content showed $15.60 \%$ in Mandvi. The minimum and maximum clay in Bhadreswar and Tuna port were observed $14.9 \%$ and $21.29 \%$, respectively. The maximum sand content showed $65.30 \%$ in Mandvi. The minimum sand content showed $54.26 \%$ in Tuna port (fig.2).

TOC of soil average range recorded is $0.01729 \%$. Mandvi soil recorded the highest range of TOC $0.01473 \%$ during the study, where at other locations in coastal area soil of at tuna port, Bhadreswar and jakhau's soil recorded found to be $0.01218 \%$, $0.004043 \%, 0.001823 \%$. Jakhau soil recorded the minimum range of TOC $0.001823 \%$ (fig.3).

$\mathrm{pH}$ of soil average range recorded is $7.5 \mathrm{pH}$. Bhadreswar soil recorded the highest range of $\mathrm{pH} \mathrm{8.1,} \mathrm{where} \mathrm{other} \mathrm{locations} \mathrm{in}$ coastal area soil of at Mandvi, tuna port and jakhau soil $\mathrm{pH}$ found to be $7.1,7.5,7.5$. Mandvi soil recorded the minimum range of $\mathrm{pH} 7.0$ (fig.4).

\section{Preparation of soil sample}

Allow the soil samples to air dry for 45 days.crush the soil samples and sieve them. Take $100 \mathrm{gm}$ sieved soil sample and add $200 \mathrm{ml}$ distilled water into it. Keep that sample in shaker for $24 \mathrm{hrs}$ filter the samples and using them for analyzing the physic chemical characterization.

\section{Physico-chemical characteristics}

The following methods were adopted to completely characterize the soil and Water samples. pH:- Prepared 1:2 soil solution was agitated thoroughly for 30 minutes to stabilizer the $\mathrm{pH}$. The same procedure was adopted for each sample. Electrical conductivity Prepared 1:2 soil solutions was agitated thoroughly for 30 minutes to stabilizer the Electrical conductivity. Soil Texture: - Take 100gm soil samples. The samples were paused through different mesh sizes as per went worth scale, i.e. $1 \mathrm{~mm}$ (stones and gravels), $0.5 \mathrm{~mm}$ (coarse sand) and $0.25 \mathrm{~mm}$ (clay) sieves. The receiving tray was used for the collection of medium fine silt and clay. Weight the collected soil samples. Total organic carbon TOC was estimated by Walkley and Rapid Titration method. Chloride:-Chloride in the water extract of the soil can be determined by titrating against AgNO3. Sodium was estimated by flame photometer method, Calcium EDTA titration method Magnesium EDTA titration method Total Hardness:-Total Hardness in the soil was determined by EDTA titration method, Potassium was estimated by flame photometer method, Alkalinity Total alkalinity in the soil was determined by standard sulphuric acid.
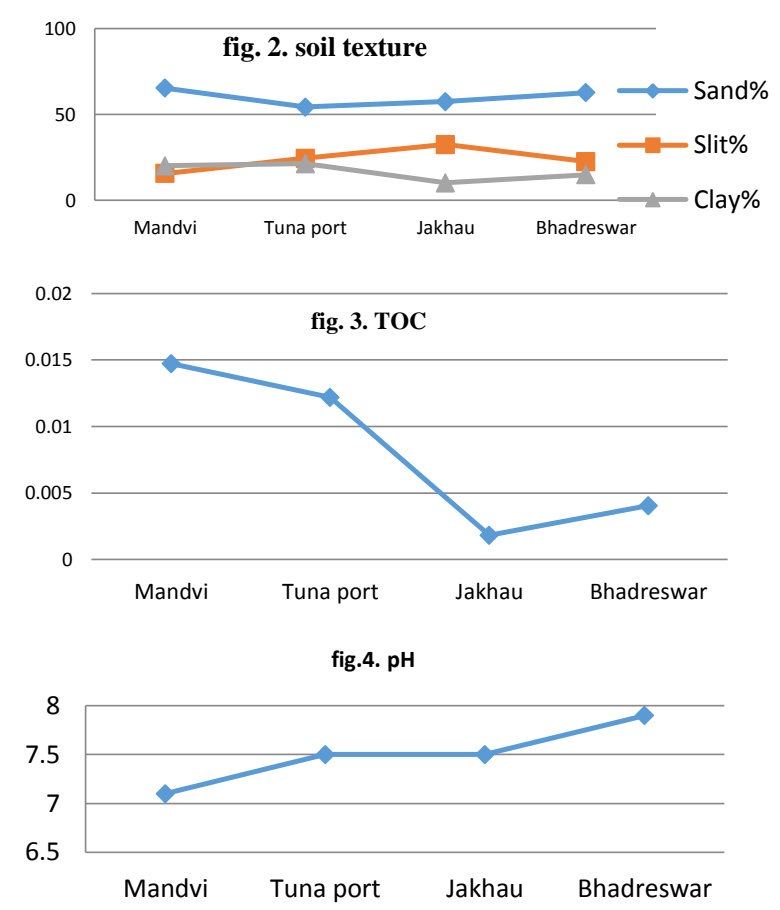
EC of soil average range recorded is $16.33 \mu \mathrm{s} / \mathrm{cm}$. Jakhau soil recorded the highest range of EC $20.432 \mu \mathrm{s} / \mathrm{cm}$, where other locations in coastal area soil of at Bhadreswar tuna port and jakhau soil EC found to be $15.484 \mu \mathrm{s} / \mathrm{cm}, 17.302 \mu \mathrm{s} / \mathrm{cm}, 20.326$ $\mu \mathrm{s} / \mathrm{cm}$. Mandvi soil recorded the minimum range of EC 12.115 $\mu \mathrm{s} / \mathrm{cm}$ (fig.5).

Sodium of soil average range recorded is $190 \mathrm{mg} / \mathrm{l}$. Bhadreswar soil recorded the highest range of sodium $200 \mathrm{mg} / \mathrm{l}$ during the study, where at other locations in coastal area soil of at Mandvi, tuna port and jakhau's soil recorded found to be $184 \mathrm{mg} / 1$, $197 \mathrm{mg} / 1,179 \mathrm{mg} / \mathrm{l}$. jakhau soil recorded the minimum range of sodium 179mg/l. (fig.6).

Calcium of soil average range recorded is $0.23375 \mathrm{mg} / \mathrm{l}$. Tuna port soil recorded the highest range of calcium $0.483 \mathrm{mg} / \mathrm{l}$ during the study where at other locations in coastal area soil of at Mandvi, Bhadreswar and jakhau soil recorded found to be $0.033 \mathrm{mg} / \mathrm{l}, 0.323 \mathrm{mg} / \mathrm{l}, 0.096 \mathrm{mg} / \mathrm{l}$. Mandvi soil recorded the minimum range of calcium $0.033 \mathrm{mg} / \mathrm{l}$ (fig.7).

Magnesium of soil average range recorded is $0.40075 \mathrm{mg} / \mathrm{l}$. Bhadreswar soil recorded the highest range of Magnesium 0.69 $\mathrm{mg} / \mathrm{l}$ during the study, where at other locations in coastal area soil of at Mandvi, tuna port and jakhau's soil recorded found to be $0.313 \mathrm{mg} / \mathrm{l}, 0.18 \mathrm{mg} / \mathrm{l}, 0.42 \mathrm{mg} / \mathrm{l}$. Tuna soil recorded the minimum range of Magnesium $0.18 \mathrm{mg} / \mathrm{l}$ (fig. 8 ).

Total Hardness of soil average range recorded is $0.635 \mathrm{mg} / \mathrm{l}$. Bhadreswar soil recorded the highest range of Hardness 1.01 $\mathrm{mg} / \mathrm{l}$ during the study, where at other locations in coastal area soil of at Mandvi, tuna port and jakhau's soil recorded found to be $0.35 \mathrm{mg} / 1,0.66 \mathrm{mg} / \mathrm{l}, 0.52 \mathrm{mg} / \mathrm{l}$. Mandvi soil recorded the minimum range of Total Hardness $0.35 \mathrm{mg} / \mathrm{l}$ (fig. 9).

Chloride of soil average range recorded is $3.552 \mathrm{mg} / \mathrm{l}$. Bhadreswar soil recorded the highest range of chloride $5.7 \mathrm{mg} / \mathrm{l}$ during the study, where at other locations in coastal area soil of at Mandvi, tuna port and jakhau's soil recorded found to be $0.71 \mathrm{mg} / \mathrm{l}, 3.6 \mathrm{mg} / \mathrm{l}, 4.2 \mathrm{mg} / \mathrm{l}$. Mandvi soil recorded the minimum range of chloride $0.71 \mathrm{mg} / \mathrm{l}$ (fig. 10).
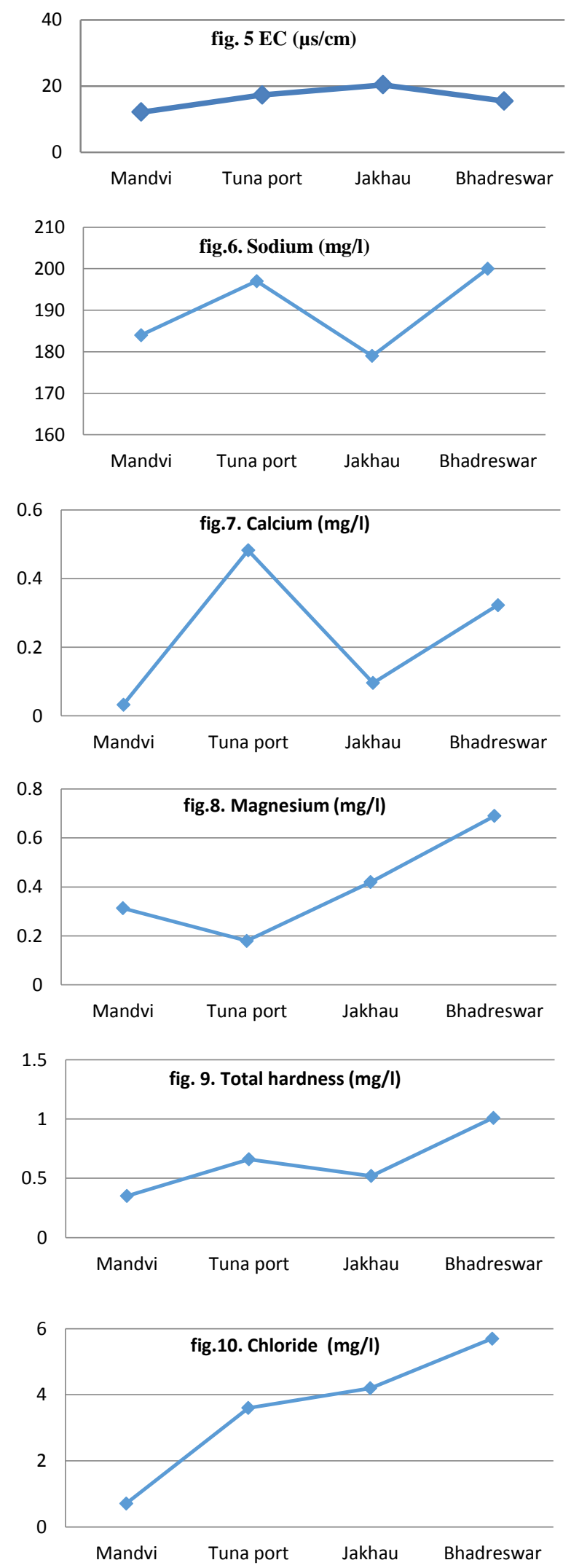
Potassium of soil average range recorded is $106 \mathrm{mg} / \mathrm{l}$ Bhadreswar soil recorded the highest range of potassium 179 $\mathrm{mg} / \mathrm{l}$ during the study, where at other locations in coastal area soil of at Mandvi, tuna port and Jakhau's soil recorded found to be $46 \mathrm{mg} / \mathrm{l}, 141 \mathrm{mg} / \mathrm{l}, 60 \mathrm{mg} / \mathrm{l}$. Mandvi soil recorded the minimum range of potassium $46 \mathrm{mg} / \mathrm{l}$ (fig.11).

Total Alkalinity of soil average range recorded is $10.84 \mathrm{mg} / \mathrm{l}$. Bhadreswar soil recorded the highest range of Total Alkalinity $26.96 \mathrm{mg} / \mathrm{l}$ during the study, where at other locations in coastal area soil of at Mandvi, Tuna port, and Jakhau's soil recorded found to be $2 \mathrm{mg} / \mathrm{l}, 3.2 \mathrm{mg} / \mathrm{l}, 11.2 \mathrm{mg} / \mathrm{l}$. Mandvi soil recorded the minimum range of Total Alkalinity $2 \mathrm{mg} / \mathrm{l}$ (fig. 12).

\section{DISCUSSION}

Soil may be defined as the naturally deposited unconsolidated material which covers the earth's surface, whose chemical, physical, and biological properties are capable of supporting plant growth. Sediments, marsh plants reduce turbidity and filter excess nutrients, chemicals, heavy metals, and other pollutants from the water. Emergent marsh plants are also able to absorb raw or treated sewage, seepage from septic systems, animal wastes, and fertilizers. When bacteria decompose these organic materials, marsh plants take up the nutrients into their roots, stems, and leaves. Physico-chemical characteristics are helpful to knowing the value surrounding the coastal area in this study.

\section{$p H$}

Soil $\mathrm{pH}$ is an important parameter of the soil. Acidity or alkalinity of the soil is always dependent on the presence of hydrogen ion concentration in the soil. The $\mathrm{pH}$ values of the soil from different plant zone of Tarkarli estuary range from 3.45 to 6.78 .which is a acidic range. The soil collected, from Mangrove is highly acidic. The soil collected at Kolamb estuary has a $\mathrm{pH}$, range 3.49 to 5.86 , a district acidic range. Usually the soil $\mathrm{pH}$ in mangroves is about 5.5 and goes up to neutrality [5, 21] Sometimes it goes beyond 7.0 as has been reported by Rao.[40, 41] The range indicates acidic to alkaline nature of the soil for different areas.[26] reported 4.3 to $7.8 \mathrm{pH}$ for soil at some places of Andaman's Island. Near salt marshes mix $\mathrm{pH}$ is reported by Heisler [12] $\mathrm{pH}$ of coastal soil Average $\mathrm{pH}$ recorded is 7.5. Soil recorded the highest range of $\mathrm{pH} 8.1$ in Bhadreswar and minimum range of $\mathrm{pH} 7.0$ in Mandvi.

\section{Electrical Conductivity}

Soil EC describes the ability of a soil to transmit an electrical current. Conductivity is measured by a probe, which applies
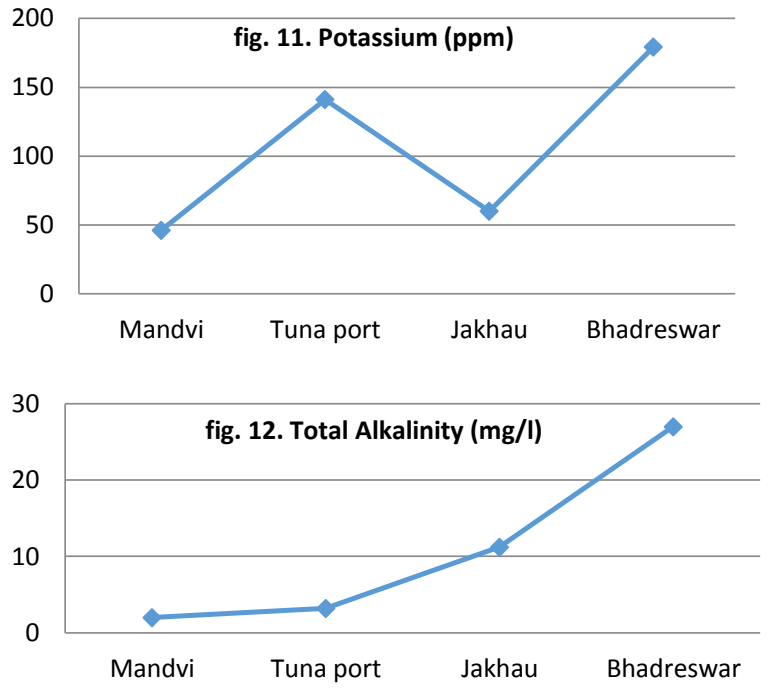

voltage between two electrodes. The drop in voltage is used to measure the resistance of the water, which is then converted to conductivity. Conductivity is reciprocal to resistance and is measured in the amount of conductance over a certain distance. [35] reported the higher electric conductivity value in natural freshwater after discharge of sugar factory effluents.

The maximum and minimum value of electrical conductivity is due to fresh water influx and mix up with ebb and f low. Similar results were reported by Rita [43]

\section{Soil Texture}

Soil texture showed $53.17 \%$ sand, $27.8 \%$ clay and silt $18.98 \%$ reported by Nole al., (2011) in mangrove soil. The highest percentage of silt content recorded $32.44 \%$ in jakhau and low percentage of soil silt content showed $15.60 \%$ in Mandvi. The minimum and maximum clay in Bhadreswar, Tuna port $14.9 \%$ and $21.29 \%$ respectively. The maximum sand content showed $65.30 \%$ in Mandvi. The minimum sand content showed $54.26 \%$ in Tuna port. Zafar [53] reported that the percentage composition of soil in the chakaria coastal areas were always found to be sand>clay>silt. Here, the soil samples recorded sand $>$ silt $>$ clay.

\section{Calcium, Magnesium and Total Hardness}

The concentration of Magnesium $(\mathrm{Mg})$ and Calcium $(\mathrm{Ca})$ are responsible for the soil hardness. In general soil hardness has been increased due to lack of water flow which cannot be washed out the $\mathrm{Mg}$ from soils. The soil of oigohaline zone of Sundarbans mangrove forest is rich in calcium followed by magnesium and potassium [27]

\section{Chloride}

The value of chloride was higher during study period might be due to high salinity, tidal flow and less fresh water mixing. 
It has been also reported that, Low value was during monsoon season due to rain and more mixing of fresh water from river and maximum value of chloride reaches in summer reported by Swaranlatha and Rao [47]

\section{Sodium and Potassium}

The higher concentration of sodium might be increased due to high salinity [25] Sodium of soil average range recorded is $190 \mathrm{mg} / \mathrm{l}$. Bhadreswar soil recorded the highest range of sodium $200 \mathrm{mg} / \mathrm{l}$ during the study, where at other locations in coastal area soil of at Mandvi, tuna port and jakhau's soil recorded found to be $184 \mathrm{mg} / 1,197 \mathrm{mg} / \mathrm{l}, 179 \mathrm{mg} / \mathrm{l}$. Mandvi soil recorded the minimum range of sodium $184 \mathrm{mg} / \mathrm{l}$. In the present study, the potassium values in all stations were slightly high. Similar results were reported Rahman [37] Potassium of soil average range recorded is $106 \mathrm{mg} / \mathrm{l}$. Bhadreswar soil recorded the highest range of potassium 179 $\mathrm{mg} / \mathrm{l}$ during the study, where at other locations in coastal area soil of at Mandvi, tuna port and jakhau's soil recorded found to be $46 \mathrm{mg} / \mathrm{l}, 141 \mathrm{mg} / \mathrm{l}, 60 \mathrm{mg} / \mathrm{l}$. Mandvi soil recorded the minimum range of potassium $46 \mathrm{mg} / \mathrm{l}$.

\section{Total organic carbon}

Kumar and Rajkumar [23] reported Total organic carbon varied from $0.29 \%$ to $2.56 \%$.maximum $1.00 \%$ and minimum $0.15 \%$ red soil organic carbon and black soil $0.54 \%$ and minimum $0.49 \%$ organic carbon reported by Physicochemical Characterization of Red and Black Soils of Wardha Region. In the present study the total organic carbon concentration of soils was found in the Average range is $0.001823 \%$ to $0.01473 \%$ from studied soil sample. whereas, the soils were recorded a minimum range in Tuna port $0.001823 \%$ and maximum range in Mandvi $0.01473 \%$

\section{CONCLUSION AND FUTURE SCOPE}

The soil samples collected from Mandvi, Tuna port, jakhau and Bhadreswar costal area during February to march 2016 and analysis of physico-chemical characteristics. The various physico-chemical parameters such as $\mathrm{pH}$, Electrical Conductivity moisture, Calcium, Magnesium, Total Hardness, Potassium, Sodium, chloride, Texture, Total organic carbon were analyzed. Texture was found Sand $>$ Silt $>$ Clay in all samples. Total organic carbon recorded maximum in soil at Mandvi and minimum at Jakhau. $\mathrm{pH}$, chloride, potassium, magnesium and sodium was found maximum at Bhadreswar while it was minimum at Mandvi. Electric conductivity was found maximum at Jakhau, while it was recorded minimum at Mandvi. Calcium was found maximum at Tuna port while it was observed minimum at Mandvi. Total Hardness was found maximum at Bhadreswar and while it was minimum at Mandvi.

\section{ACKNOWLEDGMENT}

The author's are thanks full to Department of Earth and Environmental science, KSKV Kachchh University and GUJCOST project

\section{REFERENCES}

[1] Altay, volkan and Ozturk, munir. Land degradation and halophytic plant diversity of milleyha wetland ecosystem (samandag-hatay), Turkey. Pak. J. Bot., Vol. 44: pp. 37-50.(2012)

[2] Banerjee, L. K., Rao, T. A., Sastry, A. R. K. and Ghosh, D., Diversity of coastal plant communities in India, ENVIS - EMCB Botanical Survey of India, Ministry of Environment and Forests, Kolkata. India pp. 36 (2002)

[3] Beeftink, W. G. The coastal salt marshes of western and northern Europe: an ecological and phytosociological approach. In: Wet coastal Ecosystems. (Chapman, V. J. edt.) Amsterdam, Elsevier, London, pp. 109-155. (1976)

[4] Beeftink, W. G. Salt marshes. In: The coastline. (Barnes, R. S. K. edt.) John Wiley and Sons, London, pp. 93-121. (1977)

[5] Bhosale L. J. Effect of water pollution in the areas near sea of estuarine ecosystem. Final report submitted to Department of Ocean Development, New Delhi. India pp.146 (1990)

[6] Brink, K. H. The coastal ocean progresses effort. Oceanus, 36, pp. 47-49. (1993)

[7] Brooks, Robert, T. et al. The impact of urbanization on water and sediment chemistry of ephemeral forest pools. Journal of Freshwater Ecology, Vol.17 pp. 485-488 (2002)

[8] Chakraborty, S. K. Mangrove Ecosystem of Sundarbans, India: Biodiversity of Halophytes along Gujarat coast Part- I. Mangroves: Ecology, Biology and Taxonomy. James N. Metras (Edt) (Publ. by NOVA publisher, USA). pp.83-112. (2011)

[9] Chapman, V. J. Salt marshes and salt deserts of the world. Leonard hill, London. Vol. 132 pp. 614 (1960)

[10] Dawes, C. J. Marine Botany. John Wiley and Sons, New York. Pp. 468-490. (1981)

[11] Goldberg, E. D. Competitors for coastal ocean space. Oceanus. Vol.36 (1), pp. 12-18. (1993)

[12] Heisler, N. Acid-base regulation, metabolism and energetics in sipunculus nudus as a function of ambient carbon dioxide level. J. Exp. Biol. Vol. 201(Pt 1), pp. 43-55. (1998)

[13] Jagtap, T. G. Distribution of sea-grasses along the Indian coast Aquatic Botany, Vol. 40, pp. 379-386.(1991)

[14] Jefferies, R. L. and Davy, A. J. Ecological processes in Coastal Environments. Black well, Oxford. Vol.25, Issue 5, (1979)

[15] Jenkins, M. Prospects for biodiversity. Science, Vol. 302, $1175-$ 1177. (2003)

[16] Joshi, A. J., Sagar Kumar, A. and Hinglajia, H. Effects of seawater on germination, growth, accumulation of organic compounds and inorganic ions in halophytic grass Heleochloa setulosa (Trin.) Blatt et McCann. Indian J. Plant Physiol., Vol. 7, pp. 26-30. (2002)

[17] Kannan, L. and Srinivasan, R. Marine Biodiversity, CAS in Marine Biology report, Annamalai Univ., Chidambaram, India. Pp. 146 (2000)

[18] Kavgaci, A. Sand-dune vegetation of Iğ neada coast in the Thracian part of Turkey. Hacquetia, Vol. 6 (2): pp. 171-182. (2007)

[19] Khot, S. S. Ecophysicological studies on some halophytes occurring in and around Marine National Park of India. Ph.D. Thesis Bhavnagar Univ., Bhavnagar. India pp. 123 (2003)

[20] Kirtikar, K. R. and Basu, B. D. Indian Medicinal Plants. Lalit Mohan Basu Publishers, Allahabad, India. pp. 1935-1944 (1991)

[21] Kothmire S.Y. and Bhosale L. J. Some aspects of chemical composition ofmangrove leaves and sediments. Mahasagar, Bull, Nat. Inst. Oceanogn Vol. 12(3): pp. 149-154. (1979)

[22] Krishnamurthy V. and Untwale A. G. (Ed.) Marine Plants. Seaweed research and utilization association madras: pp. 1-16 1985

[23] Kumar Rajukumar, Studies on physico-chemical characteristics and microbialdiversity of top-soil collected from proposed coal mining area of latehar district, Jharkhand. Department of Biotechnology and 
Medical Engineering National Institute of Technology Rourkela. Orissa, India. Pp. 1-83 (2013)

[24] Long, S. P. and Mason, C. F. Salt marsh ecology. Blackie and Son Ltd., Glasgow. Pp. 481-483 (1983)

[25] M. Gadhia, R. Surana and E. Ansari Seasonal Variations in Physico-chemical characteristics of Tapi Estuary in Hazira Industrial Area, Our Nature Vol.10 pp. 249-257. (2012)

[26] Mall L. P., Singh V. P., Garge A. and Pathak , S. N. Mangroves forest of Andamans and some aspects of its ecology. In L. J. Bhosale (ed) The Mangroves Proc. Nat. Symp. Biol. Uti. Cons. Mangroves, Nov. 1885. Shivaji University, Kolhapur, (India) pp. 25-38.(1986)

[27] MD. Muhibbullah et. Al Some Physico-Chemical Parameter of soil and water of Sundarban Mangrove forest, Bangladesh. Journal of Biological Sciences Vol.5 (3): pp.354-357, (2005)

[28] Misra, M. Studies on salt tolerance of Sporobolus madraspatanus Bor., a forage halophytic grass. Ph.D. Thesis, Bhavnagar Univ., Bhavnagar. India pp. 151 (1989)

[29] Mitsch, W. J. and Gosselink, J. G. Wetlands. John Wiley and Sons, New York. pp. 126 (2000)

[30] Bandyopadhya A.K. Soil and water characteristics of the mangrove forest of Sundarban (India), The Indian forester. India pp. 58-65 (1986)

[31] Nybakken, J. W. Estuaries and salt marshes.In: Marine Biology- an ecological approach. (Nybakken, J. W. edt.) An imprint of addison Wesely Longman inc. Sanfrancisco Boston, NewYork. pp. 457-462 (2001)

[32] Ozturk, M., I. Alyanak, S.Sakcali and A. Guvensen. Multipurpose Plant Systems for renovation of Waste Waters. The Arabian Journal for Science \& Engineering, 30/2C, pp:17-28. 2005

[33] Parmesan, C. Ecological and evolutionary responses to recent climate change. Annu. Rev. Ecol. Evol. S. Vol.37, pp. 637-669. (2006)

[34] Pawar, U. S. Biodiversity of halophytes along Gujarat coast part-I. $\mathrm{Ph}$. D. Thesis, Bhavnagar Uni. Bhavnagar. India pp. 125 (2012)

[35] Prabhahar et al. Soil irrigation effect of sugar mill effluent on changes of growth and biochemical contents of Raph anus sativus L. Current Botany, Vol. 2(7): pp. 09-13 (2011)

[36] Joel W. Hedgpeth, "The Shore Environment. Volume 1: Methods. J. H. Price, D. E. G. Irvine , W. F. Farnham The Shore Environment. Volume 2: Ecosystems. The systematics association special volume number 17 (a) and Number 17 (b). J. H. Price, D. E. G. Irvine, W. F. Farnham," The Quarterly Review of Biology 57, Vol. 1 pp. 77-78. 1982

[37] Rahman, A. and Ibrahim, M. Effect of cement dust deposition on physiological behaviors of some halophytes in the salt marshes of Red Sea. Egypt. Acad. J. biology Sci., Vol.3 (1): pp.1- 11. (2012)

[38] Ramachandran, S. Coastal environment and management, Institute for ocean management, Anna Univ., Chennai.Vol. 25, pp. 176-194 (2001)

[39] Ranwell, D. S. Mineral nutrient relations. In: Ecology of salt marshes and sand dunes. (Ranwell, D. S. edt.) Chapman and Hall, London, pp. 40-54. (1972)

[40] Rao, T. A. and Shanware, R. G. Ecological studies of Saurashtra coast and neighbouring islands. VI. An approach to a classification of the Saurashtra coastland - A resume. Bull. Bot. Surv. India, Vol. 9, pp. 240- 248. (1967)

[41] Rao, T. A., Aggarwal, K. R. and Mukherjee, A. K. Ecological studies of Saurashtra coast and neighbouring islands. IV. Piram island. Bull. Bot. Surv. India, Vol.8, pp.60-67. (1966)

[42] Rejith Kumar, K. S. Ecophysiology of salt tolerance in some plants growing on Gujarat coast. Ph.D Thesis, Bhavnagar University Bhavnagar. India pp. 132 (1998)

[43] Rita Chauhan and Ramanathan, A.L. Evaluation of water quality of Bhitarkanika mangrove ecosystem, Orissa, east coast of India. Indian Journal of marine sciences, Vol. 37(2): pp. 153-158.(2008)

[44] Rustaiee et al., A.R. Rustaiee, J. Khorshidi, M. Fakhr Tabatabaei, R. Omidbaigi, F. SefidkonEssential oil composition of Thymus daenensis Celak during its phenological cycle J. Essent. Oil Bear. Plants, Vol. 13 (5) (2010)

[45] Sefidkon and Rahimi bidgoli, F. Sefidkon, A. Rahimi bidgoliStudy of quality/quantity variation of oil in the Thymus kotschyanus in the period of plant growth and deferent methods of distillation Med. Arom. Plant. Res., Vol. 15, pp. 1-22 (2001)

[46] Shukla, K. H. Eco-physiological studies on salt tolerance in some halophytes. Ph. D. Thesis, Bhavnagar Uni. Bhavnagar. India pp. 125 (2007)

[47] Swarnalatha, N. and Narsing Rao. Ecological studies of Banjara Lake with reference to water pollution. Journal of Environmental Biology, Vol. 19(2): pp. 179-186.(1998)

[48] Talekar, S. D. Biodiversity of coastal flora in Bhal region part-II. $\mathrm{Ph}$. D. Thesis, Bhavnagar Univ., Bhavnagar. India pp. 128 (2009)

[49] Tansley, A. G., the British islands and their vegetation, Cambridge University Press. UK. Vol.2 (1949)

[50] Vyas, S. J. and A. J. Joshi. Mineral composition in some halophytic species of 'Bhal' region in Gujarat. Research Journal of Biology. Vol.2. pg. 99-103 (2014)

[51] M. Shiju et.al Water assessment of Kavvayi lake of northern kerala, India. Using CCMA water quality index and biological water quality criteria., Journal of Environmental biology, Vol. 37, pp. 1265-1272, 2016

[52] Yim, M.W. and N.F.Y. Tam, Effects of wastewater-borne heavy metals on mangrove plants and soil microbial activities. Marine Pollut. Bull. Vol. 39: pp. 179-186.(1999)

[53] Zafar, M., et al. Physico- chemical factors and texture of soil in solar salt farms of the Bazar coast. J. Noami, Vol. 18: pp. 27-35. (2001)

[54] Zahoor, I., Ahmad, M. Hameed, M., Nawaz, T. and Tarteel, A. Comparative salinity tolerance of Fimbristylis dichotoma (L.) Vahl and Schoenoplectus Juncoides (Roxb.) Palla, the candidate sedges for rehabilitation of saline wetlands. Pak. J. Bot., Vol. 44 (SI1): pp. 1-6. (2012)

[55] Namrata Yadav, "Physico-chemical Soil Quality Indicators as Influenced by Different Soil Management Practices in Central India", International Journal of Scientific Research in Biological Sciences, Vol.2, Issue.2, pp.9-15, 2015. 